\title{
The literature of the Tatars of the Grand Duchy of Lithuania - characteristics of the Tatar writings and areas of research
}

\author{
Magdalena Lewicka \\ Nicolas Copernicus University in Torun, Poland \\ magdalewicka@umk.pl
}

\begin{abstract}
The literature of the Tatars of the Grand Duchy of Lithuania constitutes the most important and richest part of their cultural heritage, as well as a lasting trace of Tatar settlements in the Polish-Lithuanian Commonwealth. The literature that flourished during the spiritual revival of the Renaissance and Reformation somewhere in the seemingly God-forsaken, remote Eastern Borderlands has not been forgotten; on the contrary, it has been recognised as a unique phenomenon of great spiritual, literary and cultural value. This phenomenon manifests itself in the extraordinary combination of the Oriental Islamic culture and Christian culture, two components that appear to be mutually exclusive but are in fact in perfect harmony with each other, both in the life of society and in the literary works of Polish-Lithuanian Tatars.

The paper is dedicated to literary manuscripts of the Tatars of the Grand Duchy of Lithuania, including their genesis at the background of the Tatar settlement in the territory of the Republic of Poland, characteristic features and typology of the manuscripts on the basis of the criteria of form and content. Furthermore, the author discusses the research areas, beginning with the description of the state of research on Tatar manuscripts from the point of view, through the characteristics of the current research on this matter, as well as reporting the institutions running and coordinating the interdisciplinary and international activities within the scope of the research, editing and popularization of the issues connected with the kitabistics.
\end{abstract}

Keywords

kitabistics, Tatar manuscripts, Tatars of the Grand Duchy of Lithuania, Arabic script in Belarusian and Polish

\section{Genesis of the literary manuscripts of the GDL Tatars ${ }^{1}$}

The development of the Tatar literary manuscripts and its unique character are inseparably connected with the history of the settlement of this tribe originating from the steppes of Mongolia in the territory of the Grand Duchy of Lithuania (following works discuss the history of the Tatar settlement in the territory of the former Republic of Poland: Talko-Hryncewicz, 1924; Kryczyński, 1935; 1938; 1997 1998; Tyszkiewicz, 1989; 2002; 2008; Sobczak, 1984; Borawski, 1983, 1986, 1991; Borawski \& Dubiński, 1986; Grygajtis, 2003; Łowmiański, 1983; Dumin, 1991, 2006; Kołodziejczyk, 1997;

1 Scholarly literature uses, often interchangeably, the following terms: "Polish and Lithuanian Tatars", "PolishLithuanian-Belarusian Tatars", "Polish Tatars", "Lithuanian Tatars", "Belarusian Tatars", "Tatars of the Republic of Poland", "Tatars of the Grand Duchy of Lithuania". The author uses the last one, referring to the descendants of the Golden Horde who reached the Baltic and Slavic lands in the $14^{\text {th }}$ century (in order to emphasize the Turkish Mongolian descent), due to the fact that the term "Tatar" seems to be not very precise and is used to refer to various tribes, including Turkish-Mongolian tribes, nomads who came to Middle Asia and Middle East, settlers in Russia and Crimea, members of the Golden Horde and Crimea Khanate. The terms such as "Polish Tatars", "Lithuanian Tatars", "Belarusian Tatars", based on the geographic connotations, define the contemporary national affiliation. Bearing in mind the fact that the subject of the author's discussion is the literary heritage and cultural output of the descendants of its citizens, the term "Tatars of the Grand Duchy of Lithuania" (further: GDL) seems to be most appropriate. 
Konopacki, 2006, 2010; Dziadulewicz, 1986; Katalogi zabytków tatarskich: Gutowski, 1997; Drozd, Dziekan, \& Majda, 1999, 2000; Kołodziejczyk, 1998). Its outset dates back to the time of King Gediminas's reign (1305-1341), and the first reference to Tatars living in Lithuania appears in the chronicles of the Italian Franciscan, Lucas Wadding: "Our brothers departed to proclaim the teachings of Christ in the Lithuanian lands, where they found a whole nation engulfed in the barbarian errors and dedicated to the cult of fire, among them the Scythians, coming from the country of a khan, who use Asian language in the prayers" (Borawski, 1986, p. 5), while the first information about Tatars with the name of this ethnic group is noted in Jan Długosz's chronicle: "Alexander or Vytautas the Duke of Lithuania, having reconciled with Svitrigaila, wanted to prove himself to be a Christian duke, embarked on the first raid against the Tatars. He attacked the main settlement of them, called the Horde, and many thousand barbarians with their wives, children and cattle were taken to Lithuania" (Łyszczarz, 2013, p. 74).

The Tatar settlement proceeded in two main stages, the first occurring in $14^{\text {th }}$ and $15^{\text {th }}$ centuries was connected with the flow of the Tatars from the empire of the Golden Horde and khanates located on the banks of the Volga River. This migration movement was based on the compulsory Islamization conducted by Uzbeg Khan (1312-1342), but in the end, migration to the west of Asia had not protected the Tatars from Islamization. The development of the Tatar settlement of this period can be attributed to the Grand Duke of Lithuania - Vytautas (1392-1430), who granted Tatars the land and privileges (guaranteeing the freedom of religion at the same time) in exchange for military service and help in fighting the Teutonic knights, which contributed to the massive relocation to Lithuania. The second stage of the settlement occurred between the $16^{\text {th }}$ and $18^{\text {th }}$ centuries, at first due to the settling of the war prisoners captured during the war with the Crimea Horde, and then because of the migration of the civilians from Kazan and Astrakhan Khanates fleeing from the Russian occupation. By the end of the $17^{\text {th }}$ century the Tatars settled in the territory of the Crown where King John III Sobieski granted them the demesnes in Podlasie district (the contemporary history of the Tatar community is discussed in the following works: Miśkiewicz, 1990, 1993, 2009; Miśkiewicz \& Kamocki, 2004; Czerwonnaja \& Chazbijewicz, 2014; monographs dedicated to the issues of this community include: Warmińska, 1999; Łyszczarz, 2013). After the partitions and fall of the Republic of Poland the majority of territories settled by the Tatars became part of the Tsardom of Russia, after World War I (apart from the Kaunas province belonging to the Republic of Lithuania) it was within the territory of the independent Poland. After World War II, when the Kresy (Eastern Borderlands) were lost by Poland the Tatars have been living in territory of Poland, Lithuania and Belarus (brief description of the history of the Tatar settlement in the territory of Poland, including the genesis, waves of migration, social and legal status of the settlers and their role in the military can be found in Konopacki, 2010, p. 22-58). Six hundred years' long presence in these territories (including 350 years within the current borders of Poland) made them a part of Polish nation, in particular distinguishing themselves in the military history of the Republic of Poland by participation in the fight for freedom, independence and playing an important part in all the major military events in the history of Poland: Thirteen Years' War (1458-1466), the raid of Vladislaus II of Hungary to the Czech Republic (1471), battles of Buczyna (1588), Cecora (1620), Chocim (1621), Beresteczko (1651), Polish-Swedish war (1655), Bar Confederation (1768-1772), Kościuszko Uprising (1794), November Uprising (1830) January Uprising (1863), World War I and II.

An introduction to the characteristics of the Tatar literary manuscripts should consist in their genesis, including the sources and provenance and definition of the period when they developed. As much as the discussion of the conditions of the development and traditions it is deeply rooted in is not a difficult task, the indication of the moment in time when the writings of the GDL Tatars come into existence is almost impossible. The Tatars' literary heritage includes exclusively religious literature; they had not produced (until the end of the Republic of Poland) any historic or polemical works. The only exception is the non-preserved, but mentioned in the later sources, work of Azulewicz Apologia Tatarów, issued in 1630 in Vilnius as a reply to the squib of Piotr Czyżniewski (see Konopacki, 2014). There are no relics representing the earliest period, and the first text recognized by the scholars which 
describes the Tatar society does not mention any literary activity (hence it can be deduced that Tatar books had not been written at that time), which gives rise to authenticity reservations (Risale-i Tatar-i Leh, Traktat o Tatarach polskich, of 1558, Polish translation A. Muchliński in 1858). Indirect presumptions including textological and philological analysis of the content and research on the historic context (including the influence of reformation and counter-reformation) give a basis to the assumption that the birth of the Tatar literary manuscript occurs in the second half of the $16^{\text {th }}$ century.

The determinants assumed as reasons of its development can be brought down to two factors. The first is the process of linguistic assimilation, which caused the Tatars, who were the ethnic, cultural and religious minority of the new country, to lose command of their own language (Turkic dialects) and oriental languages facilitating contacts with their co-religious (Turkish) and religious practices (Arabic) for the languages functioning in the GDL - Polish and Belorussian. The process which had been in continuous progress since the $15^{\text {th }}$ century and ended in the second half of the next century was one of the causes for undertaking the activities regarding the translation of the religious books into Slavic languages known by the Tatars, since on the one hand the doctrinal issues forced them to use the Arabic texts in the rites and liturgy, and on the other hand these texts became - under conditions of isolation from the sources and roots of Islam - the only carrier of their religious knowledge. According to Szynkiewicz (1935a, p. 141), the archetype of the manuscripts were the books written in Chagatai language, brought by the members of the Golden Horde, which seems to be confirmed by texts in this language including supplications for the religious services and the Quran surah Ja Sin present in the Tatar literature. These books were to become the basic binder allowing the GDL Tatars to retain their ethnic distinctiveness and cultural identity (Zakrzewski, 1989; Borawski, 1992), which in the $16^{\text {th }}$ century - as it seems - had been identified exclusively by their denomination - Islam (religious services and practice of the Tatar society are discussed in Konopacki, 2010). The process of the linguistic assimilation of the Tatar community was probably based on the fact that its members varied as far as their origin is concerned and used different dialects. In the light of the lack of the earlier developed feeling of the ethnic community (such a community was not created until the period of the GDL, and it was not joined by the ethnic and linguistic factors, but by a political one), their languages (dialects) originated in the steppes were not a unifying determinant, especially due to the fact that they were not the carriers of the religious traditions (Łapicz, 1986b, p. 29-30, 52-54). It is worth emphasizing that the rank of the sacral language is reserved for Arabic, as the language of the Holy Book, The Quran. However, in the Tatar liturgy and writings Turkish also played this role. In the sphere connected with religion, Tatar language was replaced by the so called Belarusian ethnolect functioning in writing and in speaking. In the sphere of the daily communication, the Tatars used Belarusian dialects, accompanied among the elite - since $16^{\text {th }}$ century - by Polish language of the northern Kresy borderland (further discussion of this subject: Drozd, 2000b; Radziszewska, 2010, p. 10-11).

The other element which certainly influenced the shaping and development of the Tatar literary output is set in the historical context, and is connected with the cultural and spiritual revival of the Republic of Poland attributed to the Renaissance and the Reformation which caused the Tatar society to create their own literature reflecting its distinctiveness and providing the core of their cultural heritage (works discussing Tatar literature and linguistic heritage - in Polish literature: Kraczkowski, 1952; Szynkiewicz, 1935a, p. 138-143; Szynkiewicz, 1932, p. 188-195; Szynkiewicz, 1935b; Woronowicz, 1935, p. 376-394; Zajączkowski, 1851, p. 307-313; Konopacki, 1966, p. 193-204; Łapicz, 1986; Łapicz \& Jankowski, 2000; Łapicz, 2008, p. 31-49; Drozd, 1999; Kulwicka-Kamińska, 2004, 2013, 2015).

\section{Characteristic features of the literary manuscripts of the GDL Tatars}

Among the characteristic features of the literary output of the GDL Tatars the following attributes have to be listed in the first place: the manuscript-like form of the books; anonymity of the authors, multilingualism resulting from the presence of the Slavic (Polish and Belarusian) and oriental (Arabic, Turkish, Persian) linguistic layer, heterogenic character (in relation to volume, genologic classification and themes), and, finally, the most distinguishing element of this literature - the way of notation 
consisting in the exclusive usage of the Arabic alphabet to write down the texts (both oriental and Slavic) included in the content of the books.

Two factors decided about the manuscript-like character of the Tatars' literary output. The first of them, particularly significant, was surely the reference to the literary output present in the world of Islam, especially regarding religious literature, which due to the high rank of the calligraphy was subjected to printing process quite late (calligraphy had been one of the key forms of art in the light of the ban on figurative representation) and in the context of the religious texts, manual copying of books became ritual in form. Additionally, the manuscript form was favoured by the local cultural context, namely the return to the manuscripts characteristic for the period of Sarmatism, for this is the period when the formation and development of the Tatar works of this kind took place (Drozd, 2000b, p. 2426).

Anonymity, as a typical feature of all the manuscript literature, is also characteristic for the discussed Tatar works. Only two names of authors, regarding these works, are known: Hodyna (Kitab of 1645) and Uriah son of Ismail (Tafsir dated for 1686), as opposed to the scribes who often disclosed their names in colophons. Surely, bearing in mind the excellent command of Arabic and other Oriental languages and the general erudition of the Tatar authors, resulting from the character of their work, including the compilation and adaptation of the texts of Slavic and Middle Eastern provenance, they were representatives of the intellectual elite of the Tatar society. What is significant in this context, the impossibility of discovering their personal information, and the following anonymous character of the Tatar literary output implicates a major hindrance in the process of chronological definition, which can only be based on the indirect presumptions: philological and contextual analysis, dates of the subsequent copies of the books, historical, social context, etc. (the subject of the authors and scribes is discussed in: Kulwicka-Kamińska, 2013, p. 57-58, 93-97, 108-110; Drozd, 2000b, p. 33-34; Konopacki, 2015, p. 271-286).

Another, immanent, feature of the Tatar manuscript output is multilingualism, reflected in the mutual interleaving of the oriental layer, in the form of such languages as Arabic, Turkish and, to a lower extent, Persian, and the Slavic layer represented by Polish spoken in the northern Kresy borderlands in the initial stage of its development and the old-Belarusian language (Drozd, 2000b; Łapicz, 1986a; Akiner, 1973, 1980). The latter contains numerous borrowings and oriental influences (Turkish and Tatar, Arabic, Persian), mostly in the range of lexis and phraseology regarding the rituals and religious beliefs. The oriental texts are, first of all, connected with the liturgy and prayer body, mostly the verses and surahs of the Quran in Arabic, as well as Arabic and Turkish prayer formulas (Drozd, 2000b, p. 1721; Kulwicka-Kamińska, 2013, p. 60-63; Łapicz, 1986a, p. 217-218). The study of such a vast and linguistically varied text requires the continuous cooperation of Slavists (especially Polonists and Belarutenists) and orientalists (especially Arabic scholars and Turkologists), due to the necessity of connecting the knowledge on Polish and Belarusian diachronic linguistics with the wide orientalistic competence (Arabic, Turkologic, Islamic) as well as theory and history of the translation of the sacred books, including theolinguistics.

As far as the most distinguishing element of this literature is concerned, namely - the way of notation, consisting in the exclusive usage of the Arab alphabet to write down both the Oriental and Slavic layer of the texts (the subject of manuscript transliteration and transcription of the Tatar literature is discussed in Teoretyczne aspekty badania piśmiennictwa Tatarów - muzułmanów Wielkiego Księstwa Litewskiego oraz Praktyka badawcza: systemy transliteracji i transkrypcji - Łapicz \& KulwickaKamińska, 2015, p. 29-202), it was the reference to the manuscript culture, especially of religious character, present in the world of Islam. The basis of adopting the Arabic alphabet instead of using the Slavic graphs, was surely a particular respect paid to religious books and Arabic writing (which was used to write down the Quran), because the sacral value was contained not only in the content of the books but also in the form of the graphs used in the notation. The Arabic alphabet was also functioning outside the Tatar literary manuscripts, namely the grave epitaphs, sacral ornamentation, and often in private writings (letters, documents, signatures of the documents), all the more that the Tatars 
preserved the ability to use the Arabic writing until $20^{\text {th }}$ century, even though their excellent command of this language was lost in the course of centuries. What is particularly significant in this context, the Arabic alphabet must have been adapted to write down the Slavic texts, or to be more precise the phonologic system of these languages through the introduction of the additional graphemes and change of the phonetic value of some existing letters.

It seems that adopting the classification proposed by Drozd (1995, p. 33-47) is most justified for the detailed and clear characteristics of the Tatar literary output. It is based on the criteria of content and form, which allows the delineation of the following types of the manuscripts: basic books including the manuscripts of The Quran, tafsirs, kitabs and chamails; auxiliary books including tajwids, sufras, vocabularies, amulets represented by dalawars, hramotkas and nuskas, and finally the last group: tables and muhirs.

Manuscripts of The Quran (ar. Al-Qur'ān - „recitation”) - are among the most popular, apart from chamails (prayer books) Tatar relic manuscripts whose basic element is the full text of the Holy Book of Islam in Arabic, enriched by sets of prayers (ar. salät) and guidelines regarding the rules of the recitation (ar. tağwīd, tilāwa), placed in the first and the last pages. Sometimes, apart from the above mentioned content components, additional information occurs, such as the list of intentions (ar. niyya), where the appropriate verses of The Quran were to be recited (ar. ayāt al-Qur'ān), or the text of the $36^{\text {th }}$ surah Ya-Sin. Manuscripts of The Quran usually number 200-300 pages, of the dominant size of $20 \times 17$ $\mathrm{cm}$. In $19^{\text {th }}$ and $20^{\text {th }}$ centuries they were owned by the majority of the Tatar families and were passed down from generation to generation. The relics of this kind are present, among others, in the following museums: Museum of History in Białystok, Lithuanian National Museum in Vilnius, Belarusian National Museum of History of Religion in Grodno, History and Archaeology Museum in Pskov, and in the library of the Belarusian Academy of Sciences in Minsk (more on this issue see in Drozd, 2000b, p. 12-13; Konopacki, 2010, p. 132-137; catalogue of the Quran manuscripts: Drozd, Dziekan, \& Majda, 2000, p. 49$50)$.

Tefsirs (ar. tafsir - „comment, explanation”) - are quite vast works containing full text of The Quran with the interlinear translation into Polish complemented with the exegetic layer. Similarly to the above described manuscripts of the Holy Book, the additional elements of the content include prayers and description of the ritual of The Quran recitation which are written on the opening and closing pages of the tafsirs. Due to the fact that these works often numbered 400-500 pages (of a set size of $35 \times 20 \mathrm{~cm}$ ) they were often ordered by a whole group of "parishioners" as a wakf (ar. waqf) for the mosque. What's quite relevant, up until the appearance of the Polish translation of The Quran in 1858, these works had remained the basic source of the Tatars' knowledge regarding the content of the Holy Book. Tafsirs are in the collections of the following museums: Lithuanian National Museum in Vilnius, in the library of the Vilnius University, Library of the Belarusian Academy of Sciences, Library of the Oriental Department of St. Petersburg University and F. Skoryna Belarusian Library in London (most comprehensive characteristics of this type of manuscripts was written by Suter, 2004; see also Drozd, 2000b, p. 13; Konopacki, 2010, p. 137-139; catalogue of tafsirs: Drozd, Dziekan, \& Majda, 2000, p. 48-49; the research on the so called Tafsir of the GDL Tatars has been conducted since 2012 by the international research team headed by prof. Łapicz of UMK in Torun, full description of the research project can be found at the Project TEFSIR website.

Kitabs (ar. kitāb - „book, booklet”) - are the relics of the manuscripts of a varied content and volume, being a type of reading matter playing educational role, usually dealing with religious matters. They contain the stories of prophets (ar. anbiyā') and other renowned characters of Islam, stories based on the Muslim traditions (ar. sunna), apocrypha, The Quran (ar. Al-Qur'ān) and the Holy Bible (ar. AlInğîl), eschatological visions, moralizing, devotional and prayer texts, hadiths (ar. hadit some surahs of The Quran, descriptions of rites and rituals (ar. farā'ị̣, arkān ad-dīn), elements of the Muslim law (ar. šarī $a$ ), religious discussions, magic texts, vocabularies of Turkish and Arabic, tajwids (ar. tağwid), and rarely, non-religious texts among which the oriental and Old-Polish texts dominate. Kitabs usually number 150-300 pages, and their sizes usually range from $35 \times 20 \mathrm{~cm}$ to $20 \times 17 \mathrm{~cm}$. In the 
$19^{\text {th }}$ and $20^{\text {th }}$ centuries, books of this type were owned by one per few or even several Tatar families. This type of the manuscripts is available in the collection of the Lithuanian National Museum in Vilnius, and the collection of the Library of the Lithuanian Academy of Sciences, Kazan University Library, British Library in London (for more on this issue, see Drozd, 2000b, p. 13-14; Konopacki, 2010, p. 139 140; catalogue of kitabs: Drozd, Dziekan, \& Majda, 2000, p. 50-54; detailed description of the so called Milkamanowicz Kitab is contained in the works by Łapicz, 1986a; 1991, p. 161-191; the relic in the collection of the London Museum is described by Akiner, 2013, p. 103-123; the so called Lebiedź Kitab is characterized by Starastsina, 2013; Lithuanian kitabs are discussed in Miszkiniene \& Temczyn, 2013).

Chamails (ar. hamā'il - „something one carries with themselves”) - are decidedly the most popular kind of Tatar manuscripts, bearing some features of a prayer book, and ,as such, containing various texts of religious themes: practical descriptions of the Muslim rituals, including ablutions (ar. wu $\bar{u}_{\bar{u}}$ ), prayers, rites of the cycle of life, name giving (ar. ādān), circumcision (ar. hitān), wedding (ar. zawāg), sets of Arabic and Turkish duai prayers (ar. $d u^{\prime} \bar{a}^{\prime}$ ), occasional formulas and devotional texts such as zikhrs (ar.

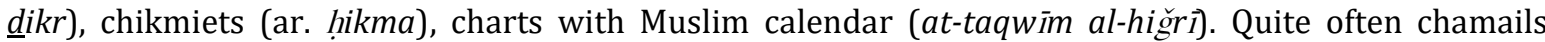
contained magic texts: prayers for chanting (curing the psychical diseases with the exorcisms), prognostics of fa'l $\left(f a^{\prime} l\right.$ ), short prayers and magical-curing formulas talsims (ar. talsim). Classifying the chamails regarding the content and purpose, two types can be distinguished: mullahian serving mullahs to do rituals and for fałdżejs (people specializing in sorcery) to do magic and fortune telling. However, very rarely do they occur in the pure form, usually they are of universal character, including both the elements of the communal rites and magical practices and the individual rites and prayers. Chamails contain 100-300 pages, their dominant sizes are $10 \times 8 \mathrm{~cm}$ or $15 \times 10 \mathrm{~cm}$. In the $19^{\text {th }}$ and $20^{\text {th }}$ centuries each Tatar family possessed one or more prayer books. Chamails are quite common in both private and museum collections, including, among others, Historical Museum in Białystok, Lithuanian National Museum in Vilnius, Belarusian National Museum of History of Religion in Minsk, National Public Library in Lvov, Library of the Arab and Islamic Studies Department of the University of Warsaw, Gdańsk Library of the Polish Academy of Sciences in Gdańsk, Library of the Belarusian Academy of Sciences in Minsk, Library of the Oriental Department of St. Petersburg University, University Library in Liepzig, and in British Library in London (more on chamails in Drozd, 2000b, p. 13-14; Konopacki, 2010, p. 141151; Chamail catalogue: Drozd, Dziekan, \& Majda, 2000, p. 54-60; a few monographs describe the so called Aleksandrowich Chamail: Szachno-Romanowicz, 1997, p. 7-25; Dziekan, 1998, p. 27-43; Dziekan, 2008, p. 81-89; Dziekan, 2013, p. 125-133; see also Radziszewska, 2013, p. 231-251; Radziszewska, 2010 - electronic copy).

Tajwids (ar. tağwìd - „The Quran recitation learning”) - are particular type of the lectures in Turkish explaining the rules of articulation (ar. qirā'a) and recitation (ar. tilāwa) of the Holy Book of Islam with the interlinear Polish-Belorussian translations. Books of this type occur sporadically; sometimes they comprise an additional element of the content of other relics of Tatar literary manuscripts such as kitabs and chamails. Relics of this type can be found in the collection of the Lithuanian National Museum in Vilnius and in the collection of the Library of the Belarusian Academy of Sciences in Minsk (for more comprehensive characteristics of tajwids, see Drozd, 2000b, p. 14; Konopacki, 2010, p. 153-154; catalogue of tajwids: Drozd, Dziekan, \& Majda, 2000, p. 60).

Sufras (ar. sifr - „book”) - are small manuscripts containing a thirtieth part of The Quran (ar. ğuz'), a type of didactic booklets used for teaching the children and including the prayers for the dead during the night preceding the funeral (ar. șalāt al-ğanāza).

Vocabularies (the name given by the scholars) - are the manuscripts containing - in accordance with the etymology of the name - lexical resources, phrases and expressions together with their translations into Polish and/or Belarusian. This type of a manuscript can be found in the collection of the Lithuanian National Museum in Vilnius (catalogue of vocabularies see: Drozd, Dziekan, \& Majda, 2000, p. 60).

Dalawars (tur. $d u^{\prime a}$ ālar - „prayers, collection of prayers”) - are the prayer scrolls put in the grave together with the deceased and they are the most lively type of the Tatar literary manuscripts since they 
function up till today. They consist of the excerpts of The Quran (chosen surahs and verses) and the principles of the faith (ar. $\bar{m} \bar{a} \bar{n})$, penitential prayers (tawba) and deliverance prayers $\left(d u^{\prime} \bar{a}^{\prime}\right)$, which are to support the dead in achieving the positive outcome of the Final Judgement (ar. Yawm ad-Din, Yawm al-Hisāb). The main part (5-15m long and 8-15 cm wide), folded into a flat package or scrolled, is put directly on the body right after it is put in the grave, while the additional parts, so called nuskas (ar. nusha) in the form of small cards are put on the dead man's forehead, mouth, chest and in their hands; slightly bigger fragments - muhirczyks - are nailed overhead to the planks fitted on the walls of the grave and hanged at the height of the dead man's chest on the perpendicular stick fixed to the wall of the grave. Dalawars are collected in the collection of the Historical Museum in Białystok and Lithuanian National Museum in Vilnius (for more on this issue see Drozd, 2000b, p. 14; Konopacki, 2010, p. 152 153; catalogue of dalawars: Drozd, Dziekan, \& Majda, 2000, p. 60-61).

Hramotkas (Belarusian: „writing, small writing”) - are the prayer scrolls worn by living people, and most rifely - apart from chamails and dalawars - represented relics of literary manuscripts of Tatars. They are also called dalawars, like the scrolls placed in the graves (they are made in a similar way and after being folded into a small package, they are worn in a little holder placed under the right arm), hence the division into funeral (sepulchral) and protective dalawars. Hramotkas, whose length is usually 2-6 m and width is 4-12 cm, contain the protective Quran verses, principles of faith, prayers (ar. $d u^{\prime} \bar{a}^{\prime}$ ) ensuring the forbearance of sins and success in the temporal life, magic formulas and shapes talismans (magical practice of Tatars is discussed in Dziekan, 2000, p. 44-47; Borawski, 1986; Aleksandrowicz, 1935; Konopacki, 2010, p. 143-149; and also elaborations on chamails). Among the protective dalawars a particular group consists of children's hramotkas, additionally containing the formulas protecting from the diseases and handed to children during the name giving celebration. Manuscripts of this type have not been included in the collections of the museums and libraries which store other relics of the Tatar manuscript output, they are in the private collections (more in Drozd, 2000b, p. 15; hramotkas catalogue: Drozd, Dziekan, \& Majda, 2000, p. 60-62).

Nuskas (ar. nusha - „piece, manuscript”) - are relics of the Tatar literary manuscripts whose character is close to hramotkas, they are often referred to as duajkas (ar. $\left.d u^{\prime} \bar{a}^{\prime}\right)$, since they come in the shape of small pieces of paper containing the excerpts from the chamail - texts of Arabic prayers, protective or healing magic formulas and shapes. They are worn in holders hanged at various parts of the body or nailed over the door-frames and dug under the doorsteps. Nuskas are in the collection of the Historical Museum in Białystok, among others (characteristics of nuskas can be found in Drozd, 2000b, p. 15; nuskas catalogue: in Drozd, Dziekan, \& Majda, 2000, p. 62).

Muhirs (tur. muhr - „stamp”) - are the ornate cards of fabric pieces containing the inscriptions or pictures of items, buildings, or places of sacral or magical character. Their function was ornamental, enriching the interiors of the houses and temples; and magic, protecting the houses and their residents. In the content of muhirs, there is a dominating motif of the text of an inscription (descriptions of rituals, prayer texts, chosen Quran verses with their translations, ethical guidelines) or presentations of the holy places accompanied by calligraphic, geometric, plant-based, architectural motifs or Muslim emblems, hence the classification according to theme criteria dividing them into inscriptional muhirs and presentation muhirs. Separate group consists of the relics whose content is in accordance with the etymology of the name - stamp muhirs, however, these occur most rarely. Muhirs are a rich part of the collection of the Historical Museum in Białystok, Lithuanian National Museum in Vilnius and Museum of the History of Religion in Grodno, they are also owned by many private owners and mosques in Kruszyniany, Bohonie, Sorok Tatary, Navahrudak, Iwie, Niemież, Śmiłowicze (detailed description of muhirs can be found in Drozd, 2000a, p. 38-43; catalogue of muhirs: Drozd, Dziekan, \& Majda, 2000, p. 67-80).

Tables (the name given by the scholars) - are paper or cardboard boards of the didactic and devotional character, placed in houses or mosques, resembling muhirs both in the form (board, sometimes framed), usage (hanged on the wall) and the content (descriptions of the rites, prayer formulas, chosen verses from The Quran with the translation, ethical guidelines). Tables are included in 
the collections of Lithuanian National Museum in Vilnius and in the mosque in Iwie (for catalogue of tables see Drozd, Dziekan, \& Majda, 2000, p. 62-63).

\section{Areas of research of the literary manuscripts of the GDL Tatars}

As far as the subjects regarding the history, religion and the culture of the Tatars of the GDL are widely covered by scientific and scholarly literature, the issues connected with the Tatar's literary manuscripts are discussed in quite a limited number of the publications. Research covering the Tatar manuscripts was undertaken mostly by orientalists and Slavists from Polish and foreign scholastic institutions, and the first author to include the information on the literary heritage seems to be an orientalist, Fleischer (1838). The catalogue he created, in the part regarding the oriental manuscripts, describes a manuscript specified by the recognized languages as Arabic-Tatar-Polish (Fleischer \& Delitzsch, 1838, p. 450). The manuscript which we today know as the chamail of Leipzig is a part of the collection of the library of the University of Leipzig, belongs to the oldest and the best preserved and available manuscripts of the Muslims of the GDL (it originates from the turn of the $16^{\text {th }}$ and $17^{\text {th }}$ centuries).

The characteristics of the state of the research on Tatar literary manuscripts up to 1966 is discussed in a paper by Konopacki (1966) entitled Piśmiennictwo Tatarów polsko-litewskich w nauce polskiej $i$ obcej (The literary writings of Polish and Lithuanian Tatars in Polish and Foreign science) which was later complemented by Reichmann (1970); according to the authors the issue became a centre of the research of the following scholars: Muchliński, and orientalist and forerunner of the research on Tatar manuscripts (1857), Łuckiewicz (1920), author of the first information regarding the 18th century kitab of Sorok-Tatary, Stankiewicz $(1933,1952)$ who researched the above mentioned manuscript, Szynkiewicz (1932, 1935a, 1935b), Woronowicz (1935), who described the textual content of the kitabs, Kryczyński (1935, 1938), Zajączkowski (1951), the author of a significant scholastic work dealing with the Tatar manuscripts, namely a sketch on the chamail of 1804 in the collection the Institute of the Orient in the University of Warsaw, Szachno-Romanowicz (1997), who - among others dealt with the fortune-telling and magical-protective texts in the manuscript known as the Aleksandrowicz chamail and, finally, Antonowicz, the author of one of the most significant work in the history of the research on the Tatar literary manuscripts: Белорусские тексты, писанные арабским письмом, и их графико-орфографическая система (Антонович, 1968). In this work he characterized 23 Tatar manuscripts in the form of books (starting from the oldest preserved and available specimens to 20th century's manuscripts) and one official document of 1759 including the state, age, form, and content with quotes of selected passages, as well as graphical and spelling features of the manuscripts' language. He also developed a system of the transliteration of the texts written with the Arabic alphabet, building the foundations for the development of the branch of science currently known as kitabistics.

The next stage of the research on the Tatar literary manuscripts is marked by the works of London scholars: Meredith-Owens and Nadson (1970), who described three manuscripts from the collection of the British Museum: tafsir of 1725, chamail of Mustapha Bohdanowicz of Słonim (1828) and kitab of the turn of the $18^{\text {th }}$ and $19^{\text {th }}$ centuries, as well as Akiner (1973), the author of a paper containing a glossary of oriental terms used in the manuscripts, developed on the basis of a kitab whose content was analyzed in the earlier publication by Meredith-Owens and Nadson (1970). The latter was also the subject of the author's later works (Akiner, 1978, 2009).

Particular contribution to the research of the Tatar manuscripts was brought by Łapicz in the form of a monograph (Łapicz, 1986a; Jankowski \& Łapicz, 2000) and paper (1991) describing the kitab of Milkamanowicz of the $18^{\text {th }}$ century, and also numerous publications treating the literary output of the GDL Tatars in general and particular approach containing the textual criticism and philology analysis of the researched materials (Łapicz, 1986b, 2005, 2008, 2009, 2015).

Tatar manuscripts have also become an object of interest of a Turkologist Drozd who dedicated some of his works to Sobolewski's chamail dated of 1905-1914 (Drozd, 1993), chamail of Petersburg of 1770 (Drozd, 1999) and chamail of Gdańsk from the collection of the library of Gdańsk branch of the 
Polish Academy of Sciences (Drozd, 1996a). In his numerous works the scholar analyzes the Tatar manuscripts in many aspects, including the influence of the Slavic surroundings on the textual content (Drozd, 1996b, 1997, 2000). The subject of kitabs has been raised a number of times by an Arabist Dziekan who dedicated some of his papers to the culture of the GDL Tatars, including the content of the Aleksandrowicz chamail from the collection of the Department of the Arab and Islamic Studies of the University of Warsaw (Dziekan, 1997a) and the analysis of the sections of this manuscript (among others, Dziekan, 2008) complementing this way the information regarding the manuscript analyzed earlier by Szachno-Romanowicz (see above). A collective achievement of both orientalists, Drozd and Dziekan, in cooperation with Majda, is the catalogue of Tatar manuscripts accessible in the territory of Poland, Lithuania, Belarus, Ukraine, Russia, Tatarstan, Germany and Great Britain (Drozd, Dziekan, \& Majda, 2000).

Miškinienè of Lithuanian academic centre is the author of numerous papers discussing the religious writings of the GDL Tatars; she also developed a Turkish-Polish dictionary being a part of the kitab of Jakub Chasiniewicz of 1840 (Miškinienè, 2008) and characterized in detail (transliterating the content and translating it into Lithuanian and Russian) three manuscripts: chamail of Leipzig, kitab of Kazan and half-kitab of Petersburg (Miškinienè, 1990, 1994a,b, 1995, 1996, 1997a, 1997b, 1997c, 1999, 2008). She also stood behind Каталог арабскоалфавитных рукописей Литовских татар (Мишкинене, Намавичюте, \& Покровская, 2005), containing the description of 83 historic manuscripts, including religious books (59 manuscripts) and single cards (24).

Catalogues (Рукапісныя і друкаваныя кнігі, 1997; Рукапісы беларускіх татараў, 2003) and publications regarding the Tatar literature are also created in Belarussian scientific centres: in their papers Tarełko and Synkowa are ordering the information about the known Tatar manuscripts, and are also analyzing the particular texts and issues (Тарэлка, 2002, 2003a, 2003b, 2004, 2008, 2013; Сынкова, 2008, 2013). A book by Tarełka and Synkowa (2009) is, in turn, an elaboration concerning the religious polemical texts of the 18th century manuscript, containing the transliteration and translation as well as a linguistic, textological, historical commentary and a glossary of terms.

A detailed study of the issues connected with the type of a manuscript which is the tafsir and generally with the religious writings of the GDL Tatars is the work of a Swiss Slavist and Arabist Suter (2004).

In the recent years, Tatar literary manuscripts have become the subject of the research of an Arabist, Lewicka who, apart from papers dedicated to kitabistics as a new scientific sub-discipline (Lewicka, 2015b, 2015c), concentrated her research interest on the Arab linguistic layer of the literary output of the Tatars of Great Duchy of Lithuania (Lewicka, 2015a, 2015d, 2015e). Arabic linguistic layer of the Tatar manuscripts has not been analyzed until now, since all the undertaken research concentrated on the Slavic layer (Polish and Belarusian languages), including the present inclusions from the oriental languages (mostly Arabic and Turkish), and aimed at reading, identifying and transliterating the textological content. The material became the basis of the scholastic research of the philological nature due to the presence of the unexplored grammar and linguistic layers of the Polish spoken in the Kresy borderlands in the period of $16^{\text {th }}-20^{\text {th }}$ centuries and interference and transference phenomena occurring within Slavic languages and Slavic-Arabic contacts on all the linguistic layers. As far as the research of the Arabic linguistic layer shall not yield such spectacular results (due to the lack of the specificity characterizing the Slavic layer with its multilingualism and one of a kind way of notation with the Arabic alphabet), they are still substantial since they allow replying the research questions and theses arising in the context of the analyses of the Tatar literary manuscripts, such as based exlusively on the Arabic layer - the ones regarding the language competence of the authors and scribes of the manuscripts and sources of the oriental texts, or - on the basis of the comparative analysis of both layers - the issues connected with the translation of the Arabic texts into Slavic languages. First of all, the subject of the research shall be the remaining copies of the $16^{\text {th }}$ century's Tafsir of the GDL Tatars preserved until contemporary times, which compose a chain of copies created in the span of four centuries $\left(16^{\text {th }}-19^{\text {th }}\right)$, not only in different periods but also in different locations and by scribes with a 
various level of the command of Arabic, which will allow the comparative analysis aiming at defining the range of the variations in the content and linguistic (and religious) competence of the particular scribes (see Lewicka, 2015a, 2015d). Subsequent stage of the research undertaken by the author shall then include the research work on the reading, transliteration, and identification of the texts present in kitabs, tafsirs, and chamails, and in turn, the textological and philological analysis of these texts.

Literary output dedicated to the Tatar manuscripts is being constantly complemented by scholars from Polish and foreign academic centres; currently the most intense works are carried out by an international team appointed in 2012, headed by professor Łapicz of Nicolas Copernicus University in Toruń. Since 2012, scholars from Poland, Lithuania, Russia and Belarus (more information about the project team can be found on the Project TEFSIR website, section "zespol-projektowy") have been working in the team realizing the project of philological and historical elaboration and critical publication of the so called tafsir of the Tatars of the Great Duchy of Lithuania (the Project TEFSIR website). The project's nature consists in the long-term team work on the documentation, research and editing of the manuscript of fundamental meaning for the heritage and culture on both national and European level. The subject of the scientific research is the first Slavic (Polish/Belarusian) - and at the same time third, after the Latin (published in 1543) and Italian translation based on it (published in 1547) - direct translation of the Quran from the Arabic original to a European language. The translation originated in the second half of the 16th century - in the period of the Reformation, when the translation of sacral books (the Bible, among others) into vernacular languages. Following the Muslim rule of $i$ ' $\breve{g} \bar{a} z$ (that is ban on translating the original Arabic Quran into other languages) this translation took a form and status of tafsir, or „comment, interpretation, explanation”. In reality, though, the manuscript tafsirs of Tatars, the Muslims of the Grand Duchy of Lithuania contain an accurate, interlinear translation of the Holy Book of Islam into contemporary Polish with elements of the (old) Belarusian. The works have been divided into four stages, the first of which consisted of the development of the rules of transliteration and transcription into the Latin alphabet of the Tatar literary manuscripts, where Polish and Belarusian languages had been written down in Arabic alphabet, and subsequently, the activities leading to standardization of the aforementioned rules and their popularization in the international kitabistic research (more information regarding the rules of transliteration and transcrpition of the Tatar historic manuscripts, developed by the team can be found at the Project TEFSIR website - section "monografia"). The second stage was concentrated on the reading of the interlinear translations of the Quran into Polish and Belarusian in the carefully selected manuscript tafsirs written in Arabic alphabet and performance of the transliteration adhering to the unified, practically verified (for authorial transliterations and transcriptions see the Project TEFSIR website - section "autorskie-transliteracje") rules developed by the team. The objective of the third stage was to specify the research areas and development of the methodological tools for the many-sided philological and historical description of the manuscript tafsirs of the GDL Tatars (about the research activities see the Project TEFSIR website - section "projekcie"). The fourth stage is dedicated to the preparation of an online publication and making the original philological resources in the form of the manuscripts of Polish and Lithuanian Tatars available in this form to scholars and researchers.

Research works that have been in progress since 2012 were one of the causes of convening a new first on the national and then on the international scale - research and scholastic unit called the Centre of Kitabistic Research (Centrum Badań Kitabistycznych, CBK) operating within the Philology Department of Nicolas Copernicus University in Torun. The Centre is headed by Kulwicka-Kamińska (Polish Language Institute) in cooperation with professor Łapicz (Russian Philology Department) and Lewicka (Arabic Language and Culture Department). The tasks of CBK include the initiation, conduction and coordination of interdisciplinary and international activities of scientific, research, editorial and popularizing character involving the kitabistics. 


\section{Conclusion}

Manuscripts of the Tatars of the Grand Duchy of Lithuania, being the most important and richest part of their heritage and a sustainable remnant of the Tatar settlement in the territory of the Republic of Poland, have been recognized as a particular aspect, a phenomenon of a kind, to which a great spiritual, literary and cultural value is ascribed. On the one hand, it is indeed an extremely rich literary output - an individual, separate literature with features which are difficult to be encountered in the literary heritage of other nations or ethnic groups. On the other hand, however, it remains a proof of a close connection between the multi-layered culture of the Great Duchy of Lithuania and the civilization of Islam, which is expressed in the extraordinary fusion of the seemingly opposed and mutually excluding elements, yet perfectly coinciding in social life and in the literary output of Polish and Lithuanian Tatars, namely - the oriental Muslim culture with Christian culture. Finally, it is a particularly valuable source of the research material, not only of philological character, but also the basis for conducting interdisciplinary, historic, ethnographic, cultural and religious studies, as well as in the range of the history of art, since some of these relics of the literary manuscripts remain on the border of the literary output and religious art.

\section{References}

AKINER, S. (2013). Treść kitabu ze zbiorów Biblioteki brytyjskiej. In Kulwicka-Kamińska, J. \& Łapicz, Cz. (Eds.), Tatarzy Wielkiego Księstwa Litewskiego w historii, języku i kulturze (p. 103-123). Toruń: Towarzystwo Naukowe.

AKINER, S. (1980). The religious vocabulary of the British Library Tatar-Byelorussian Kitab. London: University of London.

AKINER, S. (1973). The vocabulary of a Byelorussian Kitab in the British museum. The Journal of Byelorussian Studies, 3(1), 55-84.

ALEKSANDROWICZ, M. (1935). Legendy, znachorstwo, wróżby i gusła ludu muzułmańskiego w Polsce. Rocznik Tatarski, t. II, p. 368-375.

АНТОНОВИЧ, А. К. (1968). Белорусские тексты, писанные арабским письмом, и их графикоорфографическая система. Вильнюс: Вильнюсский гос. ун-т им. В. Капсукаса.

BORAWSKI, P. (1992). Asymilacja kulturowa Tatarów w Wielkim Księstwie Litewskim. Odrodzenie $i$ Reformacja w Polsce, t. XXXVI, p. 163-191.

BORAWSKI, P. (1983). Sytuacja prawna ludności tatarskiej w Wielkim Księstwie Litewskim (XVI-XVIII w.). Acta Baltico-Slavica, t. 15, 55-76.

BORAWSKI, P. (1986). Tatarzy $w$ dawnej Rzeczypospolitej. Warszawa: Ludowa Spółdzielnie Wydawnicza.

BORAWSKI, P. (1991). Tatarzy ziemianie w dobrach Radziwiłłów (XVI-XVIII w.). Przegląd Historyczny, $t$. LXXXIIP, z. 1, p. 33-49.

BORAWSKI, P. \& DUBIŃSKI, A. (1986). Tatarzy polscy. Dzieje, legendy, obrzędy, tradycje. Warszawa: Iskry.

CZERWIŃSKI, G. \& KONOPACKI A. (2015). Estetyczne aspekty literatury polskich, białoruskich i litewskich Tatarów, XVI-XXI w. Białystok: Alter Studio.

DROZD, A. (1999). Arabskie teksty liturgiczne w przekładzie na język polski XVII wieku. Warszawa: Wydawnictwo Akademickie Dialog.

DROZD, A. (1993). Chamaił Sobolewskiego. Rocznik Tatarów Polskich I, Gdańsk, p. 48-62.

DROZD, A. (2004). Koran staropolski. Rozważania w związku z odkryciem tefsiru mińskiego z 1686 roku. Rocznik Biblioteki Narodowej XXXVI, Warszawa, p. 237-248.

DROZD, A. (2000a). Na pograniczu piśmiennictwa i sztuki religijnej: muhiry Tatarów polsko-litewskich. In Drozd, A., Dziekan, M. M., \& Majda, T. (Eds.), Katalog Zabytków Tatarskich. Piśmiennictwo i muhiry Tatarów polsko-litewskich. Warszawa: Res Publica Multiethnica, p. 38-43. 
DROZD, A. (2000b). Piśmiennictwo Tatarów polsko-litewskich (XVI-XX w.). Zarys problematyki. In Drozd, A., Dziekan, M. M., \& Majda, T. (Eds.), Katalog Zabytków Tatarskich. Piśmiennictwo i muhiry Tatarów polsko-litewskich. Warszawa: Res Publica Multiethnica, p. 12-37.

DROZD, A., DZIEKAN, M. M., \& MAJDA, T. (1999). Katalog Zabytków Tatarskich. Meczety i cmentarze Tatarów polsko-litewskich. Warszawa: Res Publica Multiethnica.

DROZD, A., DZIEKAN, M. M., \& MAJDA, T. (2000). Katalog Zabytków Tatarskich. Piśmiennictwo i muhiry Tatarów polsko-litewskich. Warszawa: Res Publica Multiethnica.

DUMIN, S. (2006). Herbarz rodzin tatarskich Wielkiego Księstwa Litewskiego. Gdańsk: Związek Tatarów RP.

DUMIN, S. (1991). Szlachta tatarska w Wielkim Księstwie Litewskim i jej zmiany w sytuacji prawnej w XVI-XVIII w. Rocznik Historyczny, LVII, p. 147-163.

DUMIN, S. (2013). Tradycje genealogiczne i legendy rodowe Tatarów litewskich. In Kulwicka-Kamińska, J. \& Łapicz, Cz. (Eds.), Tatarzy Wielkiego Księstwa Litewskiego w historii, języku i kulturze. Toruń: Towarzystwo Naukowe, p. 61-89.

DZIADULEWICZ, S. (1986). Herbarz rodzin tatarskich. Warszawa: Wydawnictwa Artystyczne i Filmowe.

DZIEKAN, M. M. (1998). Chamaił Aleksandrowicza. Rocznik tatarów Polskich, IV, p. 27-43.

DZIEKAN, M. M. (2013). Chcąc znać i wiedzieć, jak ciągnąć fał alk uranowy w „Chamaile Aleksandrowicza". In Kulwicka-Kamińska, J. \& Łapicz, Cz. (Eds.), Tatarzy Wielkiego Księstwa Litewskiego w historii, języku i kulturze. Torun: Towarzystwo Naukowe, p. 125-133.

DZIEKAN, M. M. (2008). Czas święty i czas świecki w chamaile Aleksandrowicza: godziny i dni niechsiowe. In Bairašauskaite, T., Kobeckaite, H., \& Miškiniene, G. (Eds.), Orientas Lietuvos Didžiosios Kunigaikštijos Visuomenes Tradicijoje: Totoriai Ir Karaimai. Vilnius: Universiteto Leidykla, p. 81-89.

DZIEKAN, M. M. (2000). Magia i tradycje ludowe Tatarów polsko litewskich. In Drozd, A., Dziekan, M. M., \& Majda, T. (Eds.), Katalog Zabytków Tatarskich. Piśmiennictwo i muhiry Tatarów polsko-litewskich. Warszawa: Res Publica Multiethnica, p. 44-47.

FLEISCHER, H. O. \& DELITZSCH, F. (1838). Catalogus librorum manuscriptorum qui in Bibliotheca Senatoria civitatis Libsiensis asservantur. Leipzig: Grimmae, J. M. Gebhart.

GRYGAJTIS, K. (2003). Osadnictwo Tatarów hospodarskich w Wielkim Księstwie Litewskim XIV-XVIII w. Gdańsk: Związek tatarów Polskich.

GUTOWSKI, J. (1997). Katalog Zabytków Tatarskich. Broń i uzbrojenie Tatarów. Warszawa: Res Publica Multiethnica.

KOŁODZIEJCZYK, A. (1998). Cmentarze muzułmańskie w Polsce. Warszawa: OOZK.

KOŁODZIEJCZYK, A. (1997). Rozprawy i studia z dziejów tatarów litewsko-polskich i islamu $w$ Polsce $w$ XVII-XX wieku. Siedlce: IH WSRP.

KONOPACKI, A. (2015). Autorzy, kompilatorzy, kopiści - rzecz o rękopisach Tatarów Wielkiego Księstwa Litewskiego. In Kulwicka-Kamińska, J. \& Łapicz, Cz. (Eds.), Tefsir Tatarów Wielkiego Księstwa Litewskiego. Teoria i praktyka badawcza. Toruń: Wydział Filologiczny UMK, p. 271-286.

KONOPACKI, A. (2006). Muzułmanie na ziemiach Rzeczypospolitej. Białystok: ELKAM.

KONOPACKI, A. (2010). Życie religijne Tatarów na ziemiach Wielkiego Księstwa Litewskiego w XVI-XIX wieku. Warszawa: Wydawnictwo Uniwersytetu Warszawskiego.

KONOPACKI, M. (1966). Piśmiennictwo Tatarów polsko-litewskich w nauce polskiej i obcej. Przegląd Orientalistyczny, 3 (59), 193-204.

KRACZKOWSKI, I. (1952). Nad arabskimi rękopisami. Kartki ze wspomnień o księgach i ludziach. Warszawa: Państwowe Wydawnictwo naukowe.

KRYCZYŃSKI, S. (1935). Bibliografia do historii Tatarów polskich. Zamość: b. d.

KRYCZYŃSKI, S. (1997-1998). Kronika wojenna Tatarów litewskich. Gdańsk: Związek Tatarów Polskich.

KRYCZYŃSKI, S. (2000). Tatarzy litewscy. Próba monografii historyczno-etnograficznej. Gdańsk: Związek tatarów Polskich.

KULWICKA-KAMIŃSKA, J. (2014). Badania kitabistyczne w Polsce i na świecie. Życie Tatarskie, 39(116), rok X (XXVIII), 37-49. 
KULWICKA-KAMIŃSKA, J. (2004). Kształtowanie się polskiej terminologii muzułmańskiej. Na podstawie piśmiennictwa religijnego Tatarów litewsko-polskich. Toruń: Towarzystwo Naukowe.

KULWICKA-KAMIŃSKA, J. (2013). Przekład terminologii religijnej islamu $w$ polskich tłumaczeniach Koranu na tle biblijnej tradycji translatorycznej. Toruń: Wydawnictwo Naukowe UMK.

KULWICKA-KAMIŃSKA, J. \& ŁAPICZ, CZ. (2015). Tefsir Tatarów Wielkiego Księstwa Litewskiego. Teoria $i$ praktyka badawcza. Toruń: Wydział Filologiczny UMK.

KULWICKA-KAMIŃSKA, J. \& ŁAPICZ, CZ. (2013). Tatarzy Wielkiego Księstwa Litewskiego w historii, języku i kulturze. Toruń: Towarzystwo Naukowe.

KRZYŻANOWSKI, P., MIŚKIEWICZ, A. A., \& ORŁOWSKA, B. (2015), Tatarzy w Polsce po 1945 r. Muzułmańska tożsamość wobec asymilacji. Gorzów Wlkp.: Państwowa Wyższa Szkoła Zawodowa w Gorzowie Wlkp.

LEWICKA, M. (2015a). Identyfikacja i analiza tekstologiczno-filologiczna arabskiej warstwy językowej s. 478-485 Tefsiru z Olity (1723 r.). In Czerwiński, G. \& Konopacki, A. (Eds.), Estetyczne aspekty literatury polskich, białoruskich i litewskich Tatarów (XVI-XXI w.) (p. 107-132). Białystok: Alter Studio.

LEWICKA, M. (2015b). Kitabistics a new direction of the Islam studies in Poland (the literature of PolishLithuanian tatars). In Ghazali, R., Ismail, M. R., Shamsul Bahri, C. W., \& Ahmad, C. W. (Eds.), 2nd International Conference on Arabic Studies \& Islamic Civilization (p. 290-303). Kuala Lumpur: WorldConferences.Net, 00F\%20THE\%20ISLAM\%20STUDIES\%20IN\%20

POLAND\%20-\%20MAGDALENA\%20LEWICKA.pdf.

LEWICKA, M. (2015c). Piśmiennictwo Tatarów Wielkiego Księstwa Litewskiego jako trwały element dziedzictwa kulturowego i nośnik tożsamości społeczności tatarskiej na ziemiach Rzeczypospolitej. In Krzyżanowski, P., Miśkiewicz, A. A., \& Orłowska, B. (Eds.), Tatarzy w Polsce po 1945 r. Muzułmańska tożsamość wobec asymilacji (p. 135-152). Gorzów Wlkp.: Państwowa Wyższa Szkoła Zawodowa w Gorzowie Wlkp.

LEWICKA, M. (2015d). System arabskiej notacji i transliteracji. In Łapicz, Cz. \& Kulwicka-Kamińska, J. (Eds.), Tefsir Tatarów Wielkiego Księstwa Litewskiego. Teoria i praktyka badawcza (p. 101-138). Toruń: Wydział Filologiczny UMK.

LEWICKA, M. \& KULWICKA-KAMIŃSKA, J. (2012). Transformacja immanentną cechą przekładu specjalistycznego - na podstawie polskiego tłumaczenia Koranu z 2. połowy XVI wieku. Linguistica Copernicana 2012, 2(8), p. 65-75.

LEWICKA, M. (2015e). Z badań nad piśmiennictwem Tatarów polsko-litewskich. Arabska warstwa językowa Tefsiru z Olity (1723). In Abbas, A. \& Maśko, A. (Eds.), W kręgu zagadnień świata arabskiego (p. 417-433). Poznań: UAM.

ŁAPICZ, Cz. (2009). Chrześcijańsko-muzułmańska interferencja religijna rękopisach Tatarów Wielkiego Księstwa Litewskiego. In Lietuvos Didžiosios Kunigaikštystes kalbos, kulturos ir raštijos tradicijos (p. 293-310). Vilnius: Universiteto Leidykla.

ŁAPICZ, Cz. (1986a). Kitab Tatarów litewsko-polskich (paleografia, grafia, język). Toruń: Uniwersytet Mikołaja Kopernika.

ŁAPICZ, Cz. (2008). Kitabistyka a historia języka polskiego i białoruskiego. Wybrane zagadnienia. Rocznik Slawistyczny LVII.

ŁAPICZ, Cz. (1986b). Losy językowe Tatarów litewsko-polskich. Acta Universitatis Nicolai Copernici, z. 27.

ŁAPICZ, Cz. \& KULWICKA-KAMIŃSKA, J. (2015). Tefsir Tatarów Wielkiego Księstwa Litewskiego. Teoria i praktyka badawcza. Toruń: Wydział Filologiczny UMK. Available at: http://www.tefsir.umk.pl/pliki/Tefsir_Tatarow_WKL.pdf.

ŁAPICZ, Cz. (2011), Z jakich źródeł muzułmanie Wielkiego Księstwa Litewskiego czerpali wiedzę o religii chrześcijańskiej. In Lewicka, M. \& Łapicz, Cz. (Eds.), Dialog chrześcijańsko-muzułmański. Historia i współczesność, zagrożenia i wyzwania (p. 165-185). Toruń: Wydawnictwo Naukowe UMK. 
ŁAPICZ, Cz. (2005). Z zagadnień przekładu muzułmańskiej terminologii religijnej na język polski i białoruski. In Gadomski, A. (Ed.), Krymsko-polskie zeszyty naukowe (p. 165-179). Symferopol.

ŁAPICZ, Cz. \& JANKOWSKI, H. (2000). Klucz do raju. Księga Tatarów litewsko-polskich z XVIII wieku. Warszawa: Wydawnictwo Akademickie Dialog.

ŁAPICZ, Cz. (1991). Zawartość treściowa kitabu Tatarów litewsko-polskich. Acta Baltico-Slavica, t. 20, 169-191.

ŁOWMIAŃSKI, H. (1983). Studia nad dziejami Wielkiego Księstwa Litewskiego. Poznań: Wydawnictwo Naukowe UAM.

ЛУЦКЕВІЧ, І. (1920). Ай Китаб (3 пасьмертнай спадчыны Івана Луцкевіча. In Наша Нива. Зорник, Вильня, 28-39.

ŁYSZCZARZ, M. (2013). Młode pokolenie polskich Tatarów. Olsztyn-Białystok: Uniwersytet WarmińskoMazurski, Muzułmański Związek Religijny w RP.

MEREDITH-OWENS, G. M. \& NADSON, A. (1970). The Byelorussian Tartars and their Writings. The Journal of Byelorussian Studies II, 2, 141-176.

MIŚKIEWICZ, A. A. (1993). Tatarska legenda. Tatarzy polscy 1945-1990. Białystok: Krajowa Agencja Wydawnicza.

MIŚKIEWICZ, A. A. (2009). Tatarzy na Ziemiach Zachodnich Polski w latach 1945-2005 (p. 216). Gorzów Wielkopolski: Wojewódzka i Miejska Biblioteka Publiczna im. Z. Herberta.

MIŚKIEWICZ, A. A. (1990). Tatarzy polscy 1918-1939. Życie społeczno-kulturalne i religijne. Warszawa: Państwowe Wydawnictwo Naukowe.

MIŚKIEWICZ, A. A. \& KAMOCKI, J. (2004). Tatarzy słowiańszczyznq obłaskawieni. Kraków: Universitas.

MISZKINIENE, G. \& TEMCZYN, S. (2013). 0 tekstologii rękopiśmiennych kitabów Tatarów litewskich: Dialog proroka Muhammada z szejtanem. In Kulwicka-Kamińska, J. \& Łapicz, Cz. (Eds.), Tatarzy Wielkiego Księstwa Litewskiego w historii, języku i kulturze (p. 211-230). Toruń: Towarzystwo Naukowe.

МИШКИНИЕНЕ, Г. (1995а). Адаптация арабско-турецких заимствований в китабе КY-1446. In Функцыянальны аспект апісання моўных сістэм (р. 200-205), Гродно.

Мишкиниене, Г. (1997а). Идеологические споры между мусульманами и иудеями (на материале арабскоалфавитных рукописей литовских татар середины XVII в. In Temčinas, S. (Ed.), Krakowsko-Wileńskie Studia Slawistyczne, t. II (p. 234-250). Kraków.

МИШКИНИЕНЕ, Г. (1990). К проблеме транслитерации китаба ЛУ-893. Kalbotyra, XLII (2), 64-70.

МИШКИНИЕНЕ, Г. (1994а). Китаб з фондаў Казанскага Ўніверсытэту (№ 1466). In Запісы. Беларускі інстытут навукі й мастацтва XXI (p. 76-111). New York.

МИШКИНИЕНЕ, Г. (1996). О некоторых особенностях рукописи ЛУ-893. In Е. Карский $и$ современное языкознание, t. II (p. 238-242), Гродно.

МИШКИНИЕНЕ, Г. (1994b). Правовое положение татар в Великом княжестве Литовском в XVIXVII вв. (По материалам полемической литературы о литовских татарах). Kalbotyra, XLIV (2), 8591.

МИШКИНИЕНЕ, Г. (1997b). Проблемы адаптации арабизмов и тюркизмов в китабе КУ-1446. Kalbotyra XLV (2), 53-64.

МИШКИНИЕНЕ, Г. (2009а). Развитие китабистики в Вильнюсском университете. Kalbotyra, LIV (2), 231-247.

МИШКИНИЕНЕ, Г. (1997с). „Темные места” в переводе арабских и старотурецких рукописей на белорусский и польский языки в XVII в. Kalbotyra, XLVI (2), 204-215.

МИШКИНИЕНЕ, Г. (2008). Турецко-польский словарик из китаба Якуба Хасеневича (1840). In Bairašauskaitè, T., Kobeckaitė, H., \& Miškinienė, G. (Eds.), Orientas Lietuvos Didžiosios Kunigaikštijos Visuomenes Tradicijoje: Totoriai ir Karaimai (p. 105-121). Vilnius: Universiteto Leidykla.

МИШКИНИЕНЕ, Г. \& ДУРГУТ, Х. (2009b). Легенда „Мирадж” из китаба Ивана Луцкевича. In Temс̌in, S. J. (Ed.), Lietuvos Didžiosios Kunigaikštystes kalbos, kultūros ir raštijos tradicijos (p. 357-375). Vilnius: Lietuvių Kalbos Institutas. 
МИШКИНИЕНЕ, Г. \& НАМАВИЧЮТЕ, С. (2009с). Китаб Ивана Луцкевича. Памятник народной культуры литовских татар. Вильнюс: Lietuviu kalbos institutas.

МИШКИНЕНЕ, Г., НАМАВИЧЮТЕ, С., \& ПОКРОВСКАЯ, Е. (2005). Каталог арабскоалфавитных рукописей литовских татар. Вильнюс: Вильнюсский гос. ун-т им. В. Капсукаса.

Project TEFSIR website. Available at: http://www.tefsir.umk.pl/

RADZISZEWSKA, I. (2013). Praktyki magiczne w chamaiłach Tatarów Wielkiego Księstwa Litewskiego (na podstawie tzw. fału Sulejmana). In Kulwicka-Kamińska, J. \& Łapicz, Cz. (Eds.), Tatarzy Wielkiego Księstwa Litewskiego w historii, języku i kulturze (p. 231-251). Toruń: Towarzystwo Naukowe.

RADZISZEWSKA, I. (2010). Chamaiły jako typ piśmiennictwa religijnego muzułmanów Wielkiego Księstwa Litewskiego (na podstawie słowiańskiej warstwy językowej), unpublished doctorate disertation. Toruń: Uniwersytet Mikołaja Kopernika.

SOBCZAK, J. (1984). Położenie prawne ludności tatarskiej w Wielkim Księstwie Litewskim. WarszawaPoznań: Państwowe Wydawnictwo Naukowe.

STARASTSINA, V. (2013). Porównanie zawartości Kitabu Lebiedzia (z drugiej połowy XVIII w.) z zawartością innych rękopisów Tatarów Wielkiego Księstwa Litewskiego. In Kulwicka-Kamińska, J. \& Łapicz, Cz. (Eds.), Tatarzy Wielkiego Księstwa Litewskiego w historii, języku i kulturze (p. 253-274). Toruń: Towarzystwo Naukowe.

SUTER, P. (2004). Alfurkan tatarski. Der litauisch-tatarische Koran-Tefsir. Köln: Böhlau.

SYNKOVA, I. (2013). Magiczne teksty w rękopisach Tatarów WKL. In Kulwicka-Kamińska, J. \& Łapicz, Cz. (Eds.), Tatarzy Wielkiego Księstwa Litewskiego w historii, języku i kulturze (p. 275-289). Toruń: Towarzystwo Naukowe.

СЫнКОВА, I. (2008). Отражение антитринитарной полемики в литературе Татар Великого княжества Литовского. In Bairašauskaitė, T., Kobeckaitė, H., \& Miškinienè, G. (Eds.), Orientas Lietuvos Didžiosios Kunigaikštijos Visuomenés Tradicijoje: Totoriai ir Karaimai (p. 223-232). Vilninius: Universiteto Leidykla.

SZACHNO-ROMANOWICZ, S. (1997). Planetne dualary Tatarów polskich (tatarskie teksty magicznoochronne w chamaile Aleksandrowicza). Rocznik Tatarów Polskich, IV, 7-25.

SZYNKIEWICZ, J. (1935a). Literatura religijna Tatarów litewskich i jej pochodzenie. Rocznik Tatarski, 2, 138-143.

SZYNKIEWICZ, J. (1932). O kitabie. Rocznik Tatarski, 1, 188-194.

TALKO-HRYNCEWICZ, J. (1924). Muślimowie, czyli tak zwani Tatarzy Litewscy. Kraków-Dębniki: Księgarnia Geograficzna „Orbis”.

TAREŁKA, M. (2013). Pskowski Koran z 1093/1682 r. Nowe informacje. In Kulwicka-Kamińska, J. \& Łapicz, Cz. (Eds.), Tatarzy Wielkiego Księstwa Litewskiego w historii, języku i kulturze (p. 291-306). Toruń: Towarzystwo Naukowe.

ТАРЕЛКА, М. (2003а). Да пытання аб цытатах з Бібліі С. Буднага і Брэсцкай Бібліі ў рукапісе Р97 3 калекцы Цэнтральнай Навуковай Бібліятэкі НАН Беларусі. In Гісторыя выдавецкай дзейнасці ў Польшчы і Беларусі ў XVI - XX стагоддзях (р. 13-17). Мінск.

ТАРЕЛКА, М. (2002). Папярэднія звесткі аб палемічным трактаце з рукапісу Р97 Бібліятэкі НАН Беларусі. Весник, Снежань 2002, 3, 86-90.

ТАРЕЛКА, М. (2008). Рукапіс Р98 (таджвід) з фондаў Цэнтральнай Навуковай Бібліятэкі НАН Беларусі (праблема датування і вызначэння жанру). In Bairašauskaitè, T., Kobeckaitė, H., \& Miškinienė, G. (Eds.), Orientas Lietuvos Didžiosios Kunigaikštijos Visuomenès Tradicijoje: Totoriai ir Karaimai (p. 123-129). Vilnius, Lithuania.

TYSZKIEWICZ, J. (1989). Tatarzy na Litwie $i$ w Polsce. Studia z dziejów XIII-XVIII w. Warszawa: Państwowe Wydawnictwo Naukowe.

TYSZKIEWICZ, J. (2008). Tatarzy $w$ Polsce i Europie. Fragmenty dziejów. Pułtusk: Akademia Humanistyczna im. A. Gieysztora.

TYSZKIEWICZ, J. (2002). Z historii Tatarów polskich 1794-1944. Zbiór szkiców z aneksami źródłowymi. Pułtusk: Wyższa Szkoła Humanistyczna. 
WARMIŃSKA, K. (1999). Tatarzy polscy - tożsamość religijna i etniczna. Kraków: Towarzystwo Autorów i Wydawców Prac Naukowych „Universitas”.

WORONOWICZ, A. (1935). Kitab tatarów litewskich i jego zawartość. Rocznik Tatarski II, p. 376-394.

ZAJĄCZKOWSKI, A. (1951). Tak zwany chamaił tatarski ze zbiorów rękopisów w Warszawie. Sprawozdania z Czynności i Posiedzeń PAU LII, 4, 307-313.

ZAKRZEWSKI, A. B. (1989). O asymilacji Tatarów w Rzeczypospolitej w XVI-XVIII w. In Bogucka, M. (Ed.), Tryumfy i porażki. Studia z dziejów kultury polskiej XVI-XVIII w. (p. 76-96). Warszawa: Państwowe Wydawnictwo Naukowe.

\section{Contact}

Magdalena Lewicka, PhD

Pracownia Języka i Kultury Arabskiej UMK

Ul. Bojarskiego 1

87- 100 Toruń

Poland

magdalewicka@umk.pl 